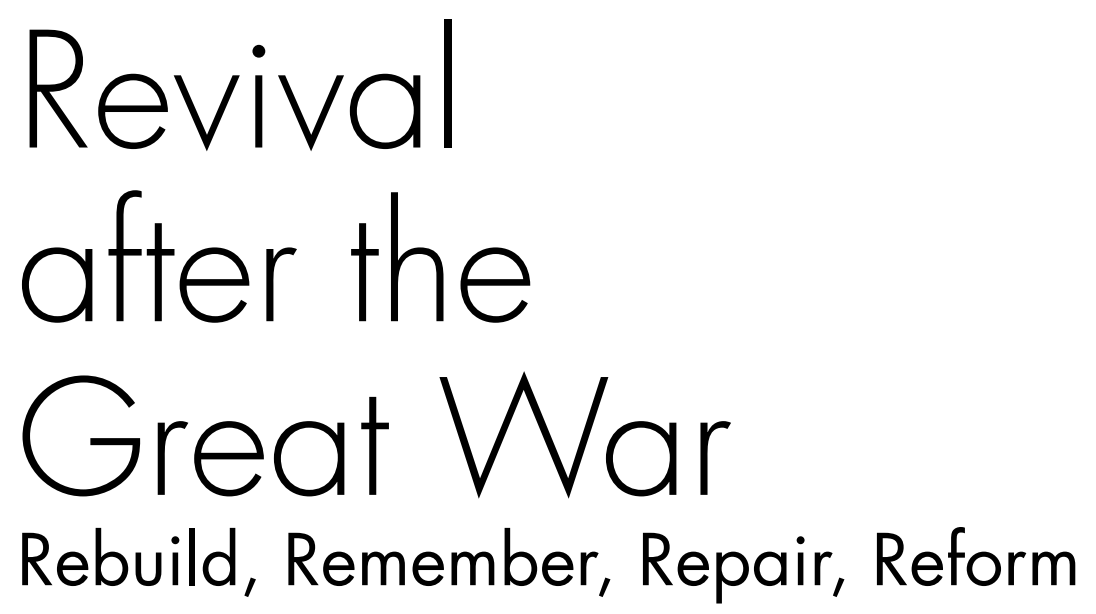

Edited by

Luc Verpoest, Leen Engelen,

Rajesh Heynickx, Jan Schmidt,

Pieter Uyttenhove, and Pieter Verstraete 
Published with the support of the KU Leuven Fund for Fair Open Access, the City of Leuven and LUCA School of Arts

\section{KULEUVEN}

\section{LEUVEN}

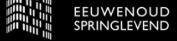

Published in 2020 by Leuven University Press / Presses Universitaires de Louvain / Universitaire Pers Leuven. Minderbroedersstraat 4, B-3000 Leuven (Belgium). (C) 2020 Selection and editorial matter: Luc Verpoest, Leen Engelen, Rajesh Heynickx, Jan Schmidt, Pieter Uyttenhove, and Pieter Verstraete (C) 2020 Individual chapters: The respective authors

This book is published under a Creative Commons Attribution Non-Commercial NonDerivative 4.0 International Licence.

\section{() $\Theta \Theta$}

The license allows you to share, copy, distribute, and transmit the work for personal and non-commercial use providing author and publisher attribution is clearly stated. Attribution should include the following information:

Luc Verpoest, Leen Engelen, Rajesh Heynickx, Jan Schmidt, Pieter Uyttenhove, and Pieter Verstraete (eds.). Revival after the Great War: Rebuild, Remember, Repair, Reform. Leuven, Leuven University Press. (CC BY-NC-ND 4.0)

Further details about Creative Commons licenses are available at http://creativecommons.org/licenses/

ISBN 9789462702509 (Paperback)

ISBN 9789461663542 (ePDF)

ISBN 9789461663559 (ePUB)

https://doi.org/10.11116/9789461663542

$\mathrm{D} / 2020 / 1869 / 60$

NUR: 648

Layout: Friedemann Vervoort

Cover design: Anton Lecock

Cover illustration: A family posing on the Old Market in Leuven (Belgium) around 1921. (๔ City Archive Leuven) 


\section{Table of Contents}

Acknowledgements

Introduction

Revival After The First World War: Rebuild, Remember, Repair, Reform

Luc Verpoest, Leen Engelen, Rajesh Heynickx, Jan Schmidt, Pieter Uyttenhove \& Pieter Verstraete

\section{PART ONE — REBUILD}

Catastrophe and Reconstruction in Western Europe: The Urban Aftermath of the First World War Pierre Purseigle

Reflections on Leuven as Martyred City and the Realignment of Propinquity Richard Plunz

Making Good Farmers by Making Better Farms: Farmstead Architecture and Social Engineering in Belgium After the Great War Dries Claeys \& Yves Segers

“C'est la beauté de l'ensemble qu'il faut viser.": Notes on Changing Heritage Values of Belgian Post-World War I Reconstruction Townscapes Maarten Liefooghe

Rebuilding, Recovery, Reconceptualization: Modern architecture and the First World War Volker M. Welter

\section{PART TWO — REMEMBER}

Reclaiming the Ordinary: Civilians Face the Post-war World Tammy M. Proctor

Expressing Grief and Gratitude in an Unsettled Time: Temporary First World War Memorials in Belgium 
Remembering the War on the British Stage: From Resistance to Reconstruction

Helen E. M. Brooks

A War to Learn From: Commemorative Practices in Belgian Schools After World War 1

Kaat Wils

\section{PART THREE — REPAIR}

High Expectations and Silenced Realities: The Re-education of Belgian Disabled Soldiers of the Great War, 1914-1921

Pieter Verstraete and Marisa De Picker

Back to work: Riccardo Galeazzi's Work for the Mutilated Veterans of the Great War, Between German Model and Italian Approach Simonetta Polenghi

Competition over Care: The Campaign for a New Medical Campus at the University of Leuven in the 1920s

Joris Vandendriessche

\section{PART FOUR — REFORM}

An Argentine Witness of the Occupation and Reconstruction of Belgium: The Writings of Roberto J. Payró (1918-1922) María Inés Tato

The New Post-war Order from the Perspective of the Spanish Struggle for Regeneration (1918-1923)

Carolina García Sanz

The Act of Giving: Political Instability and the Reform(ation) of Humanitarian Responses to Violence in Portugal in the Aftermath of the First World War

Ana Paula Pires

Reconstruction, Reform and Peace in Europe after the First World War John Horne

Bibliography

List of Contributors 


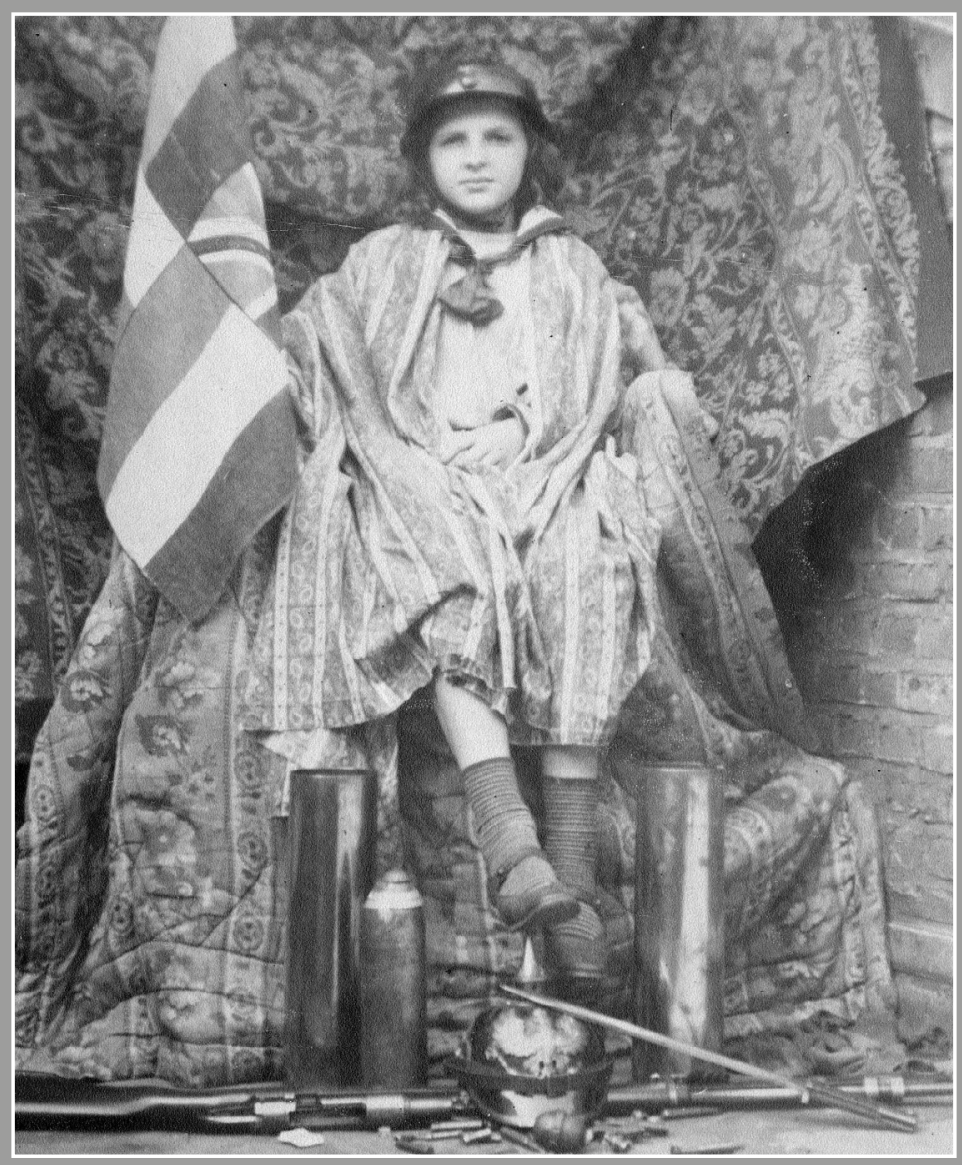

PART TWO

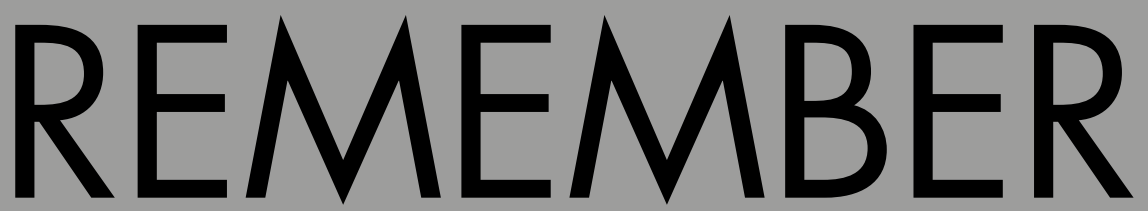


Family photograph of a patriotic tableau vivant re-enactment, Leuven (Belgium), 1919.

(c) Family Archive Kristien Stals 
Now all roads lead to France And heavy is the tread Of the living; but the dead Returning lightly dance:

Whatever the road bring To me or take from me, They keep me company With their pattering,

Crowding the solitude Of the loops over the downs, Hushing the roar of towns and their brief multitude.

Edward Thomas, excerpt from Roads (1915-1917) 


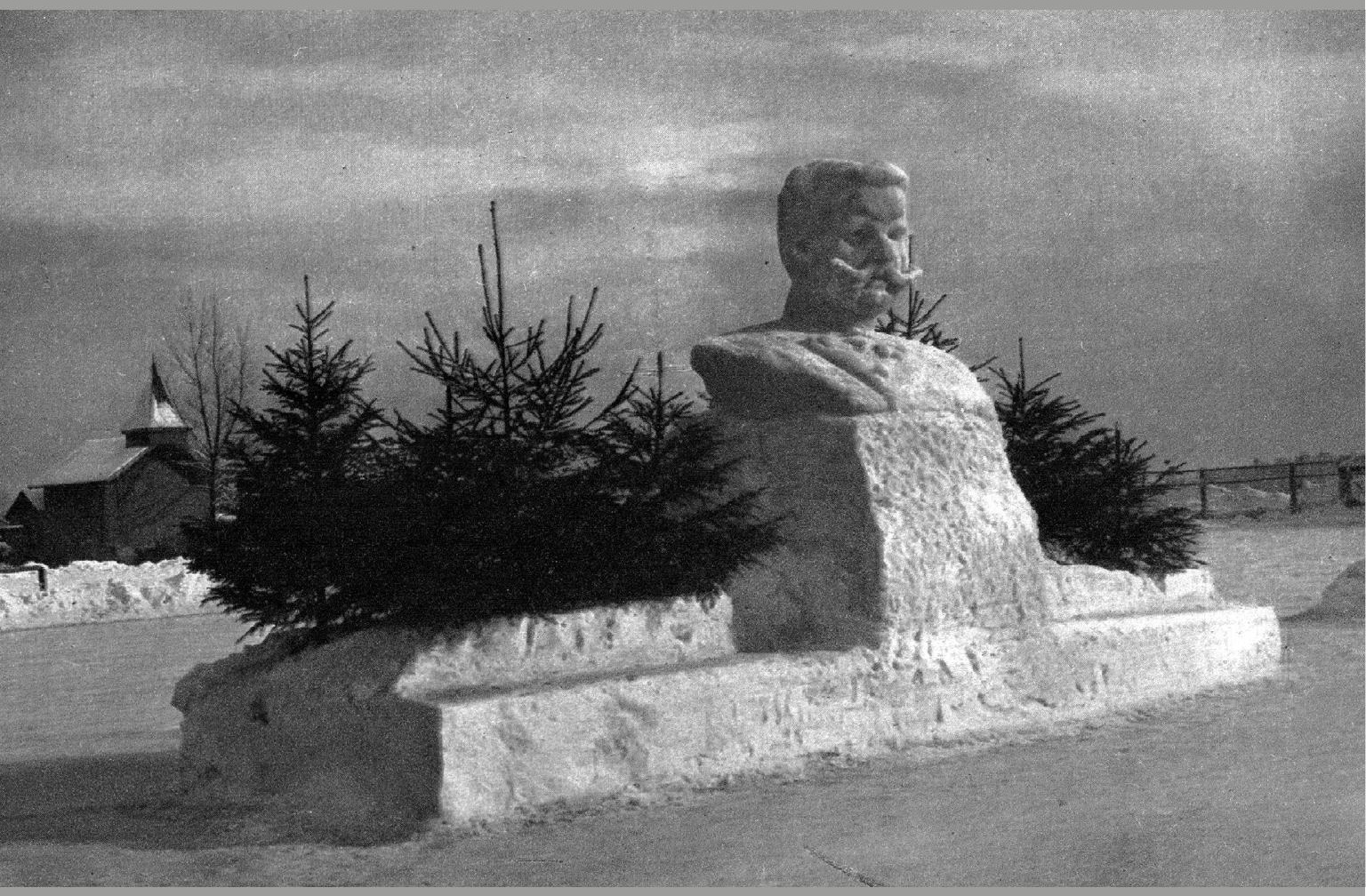

Fig. 1. Karl Gläser, Monument to German

Field Marshal Paul von Hindenburg,

executed in snow, 1915, Stuttgart, Ice

skating rink. Picture postcard, F. Hinderer

Verlag. (private collection) 


\title{
Expressing Grief and Gratitude in an Unsettled Time
}

\section{Temporary First World War Memorials in Belgium}

Leen Engelen \& Marjan Sterckx

\section{Introduction: Temporary Monuments and the Great War}

\begin{abstract}
There will be, there would be, if one is not careful, something atrocious: memorials! Let's denounce this peril. Certainly, let's write the names of the martyrs in bronze and marble on the threshold of our village halls; let's plant commemorative trees [...]; let's erect in some larger cities the column or temple that eternalises the painful image of this grand era. But, let's be wary of cheap memorials of poor quality, a threat that is surrounding us on all sides. [...] Can you see that? [...] on all the squares, a Lady Belgium in bronze by a local artist [...] To make things worse, no doubt every Lady Belgium will be accompanied by a lion, that formidable Belgian lion. ${ }^{1}$
\end{abstract}

This warning against a deluge of average-quality war memorials was published in the Belgian satirical magazine Pourquoi Pas? as early as December 1918. In his bantering critique, the author was referring to the thousands of memorials that had been erected in French villages after the Franco-Prussian war. Alas, his warning fell on deaf ears. As of November 1918, and continuing well into the 1920s and 1930s, a large number of monuments commemorating the Great War were erected throughout France and Belgium. Although the act of commemorating conflict through monuments indeed long predated the Great War, no previous war had instigated the creation of such a 
large number of memorials. ${ }^{2}$ In formerly occupied territories such as the majority of Belgium and Northern France, the need to express grief as well as gratitude had been actively suppressed by the occupational regime for over four years. The occupation army's departure triggered a rapid and intense surfacing of the need to create monuments. Instantaneously and enthusiastically, ideas began to surface on both the national and local levels and many of these initiatives involved active and intense public participation. Plans were forged by formal as well as informal local associations such as parishes, professional guilds, schools, (sports) clubs and neighbourhood associations. Occasionally, independent initiatives were taken by bereaved families or individual artists. Only a minority of these intentions actually materialised and many took a long time to develop. ${ }^{3}$

This essay looks into a phenomenon which slightly predates the large-scale postwar "statue mania" that flooded municipal squares and parish grounds starting in the early 1920s. We will explore the emergence of temporary public memorials in Belgium during and immediately after the First World War, assessing how they developed and established a commemoration trajectory which lasted for decades. Although ephemeral monuments were an international phenomenon characterised by a great diversity, they took on a specific form in (previously) occupied territories such as Belgium, both during and after the war. These monuments - made of temporary materials such as greenery, wood, earth and plaster - were created with the intention of alleviating the urgent (and sometimes long repressed) need for a place of remembrance, a lieu de mémoire. They emerged from a deeply felt and shared desire to mourn, remember and commemorate singled-out (groups of) people, specific war-related events or causes. They emerged from below in the absence of official permanent monuments - which usually came about via top-down procedures - and were often conceived to structure collective commemorations and commemorative practices according to familiar, ritualised patterns. In his essay on "The Living", John Horne describes people's coming to terms with death in wartime as a process which takes place in three concentric circles: the innermost circle is the private loss of a loved-one, the second circle is the formation of temporary mourning communities (small-scale to nationwide) and, finally, the third circle - public commemoration - gives mourning an enduring public form. In general, the early temporary monuments are firmly rooted in the innermost circle. They develop within small mourning communities and sometimes - if their replacement by a permanent structure is envisaged - they are the harbinger of enduring commemoration. ${ }^{4}$ As such, they play their part in private, collective as well as public processes of mourning and healing. Through involvement people gained the opportunity to do more than just visit the monuments and leave flowers and wreaths: in what were often grassroots initiatives, they could also participate in their conceptualisation and collaborate in their creation. At the same time, hierarchical committees (such as parish groups or comités de patronage) 
often played some part in their realisation. These memorials often were conceived and constructed in a short time. Therefore, they mostly by-passed the generally cumbersome official procedures for erecting public monuments and were able to disregard conflicting agendas of official bodies as well as aesthetic discussions. It was often hoped that before these ephemeral monuments deteriorated, regular top-down procedures would lead to their replacement with permanent structures in stone or bronze. In a way, the ephemeral character of the monuments created a kind of a space "in between": their presence eased an immediate need and thereby gave communities and authorities time to think about durable monuments and future commemorative practices. When in the early 1920s an increasing number of permanent memorials were built, their temporary predecessors quickly began to disappear.

In order to contextualise the emergence and meaning of ephemeral First World War memorials in Belgium, we will shed light on the different historic and international manifestations of this phenomenon before, during and after the First World War. First, we will show that in the context of the Great War temporary memorials were an international phenomenon that manifested itself in many different forms depending on the place where they emerged and those involved in their conception. Next, we will show that these temporary monuments took a specific shape in occupied areas such as Belgium, both during and after the war. In our discussion we will pay attention to the variable temporalities of different types of temporary monuments and to the changing roles played by the various stakeholders (the public, the authorities, the artists).

\section{Wartime Temporary Memorials: An International Phenomenon}

The specific nature of the Great War partly accounts for the popularity of temporary monuments in the countries directly involved in the conflict. For the first time, a total war was being fought and the consequences of war were forced home on civilians. The massive involvement of citizens revealed that the general population had a pressing urge to commemorate or celebrate specific and often local events or to come together to publicly express and share grief. These needs had already begun to arise during the conflict. Although the circumstances differed depending on the country or region, the erection of ad hoc, co-created, do-it-yourself memorials, such as flower shrines or modest wooden columns or crosses, was an international phenomenon that manifested itself in many different forms. Some early British instances are well documented. As early as October 1914, for example, the London fire brigade proposed to honour its fellow firemen who fell in the first weeks of the war (five by then) by erecting a temporary memorial at the brigade's headquarters. 
The memorial was erected as an immediate, emotional response to the loss this local community of firemen was confronted with and became a tangible symbol for their grief. ${ }^{5}$ In 1916, likewise in London, inhabitants of a working-class neighbourhood in the East End marked the voluntary enlistment of 65 of their boys and men with a street shrine. Their example was followed by several other neighbourhoods in the area and led to what came to be called the "war shrine movement". ${ }^{6}$ As the movement caught on, institutional (funding) bodies such as parishes and local governments quickly became involved and a standard design was proposed. By the end of October 1916, more than 250 shrines had been erected or were planned and many more would follow. ${ }^{7}$ Evidently, public wartime shrines such as these British examples were rare to non-existent in occupied or frontline areas. In Britain, these early initiatives often already carried within them the intention for a later permanent memorial. In August 1916, the British parish of Dorking for example erected "a handsome oak cross with a figure of bronze representing Christ crucified" along with the roll of honour of the parish. Immediately, it was made clear that this was "only intended to be a temporary memorial, to suffice until the end of the war, when, doubtless the town will desire something of a more enduring character shall take its place", as indeed many communities envisaged. ${ }^{8}$ As Mark Connelly argues, the war shrines indeed laid the foundations for later remembrance, but this was by no means a paved way and many hurdles lay ahead. ${ }^{9}$ A case in point is the Hyde Park memorial shrine: a 24-foot spire with Allied flags around the top placed on a Maltese-cross-shaped base. It was inaugurated on 4 August 1918 and attracted vast audiences. ${ }^{10}$ Due to its popularity, the shrine remained in situ for over a year and prompted debates on official war memorials. Architect Edwin Lutyens (1869-1944) was asked to design a monument to replace the temporary shrine, but this project never materialised. ${ }^{11}$

Some temporary memorials inscribed themselves in more vernacular practices. An out of the ordinary example are the snow memorials. These are at once rooted in the popular pastime of snow sculpting and in the artistic tradition of open-air snow and ice sculpture exhibitions, commonly organised during frost fairs. The latter were quite popular in the Low Countries during the Little Ice Age that struck Europe from the fourteenth to the nineteenth century. In some cases, the extremely ephemeral nature of snow sculptures occasioned more daring or even provocative designs or themes. ${ }^{12}$ This was not the case when, in January 1915, a snow sculpture of the German Field Marshal Paul von Hindenburg (1847-1934) - at that time already known in Germany as "the victor of Tannenberg" - was unveiled in Stuttgart. The large bust of Hindenburg in uniform (complete with iron cross) was placed on a massive rectangular plinth and flanked by pine trees (Fig. 1). The structure was approximately three metres high. The almost alabaster or marble white of the snow as well as its transient qualities stood in stark contrast to the serious posture of the 
bust and the stately elaboration of the plinth in an imitation granite texture. As it was placed in an outdoor ice rink, people skated around the statue, which was guarded by two guards on ice skates. Before it melted, this first memorial to Hindenburg in Germany was documented in articles in the local press, press photos, a Messter Woche newsreel item and picture postcards. ${ }^{13}$

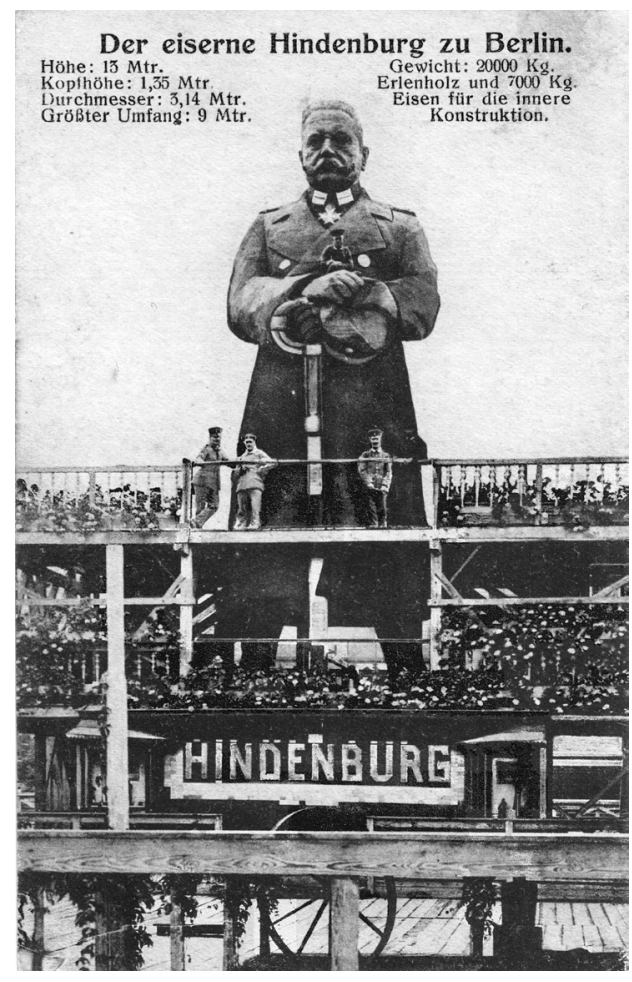

Fig. 2. Georg Marschall, Der Eiserne Hindenburg zu Berlin, erected in 1915 in Berlin. Picture postcard, Oscar Peters Verlag, Darmstadt. (private collection)

This type of documentation - more long-lasting than the objects themselves - also exists in relation to a so-called Nagelman (nail man) sculpture of the same Hindenburg which was erected in Berlin in the autumn of 1915. In the years that followed, the 13-metre-high wooden structure by German painter and sculptor Georg Marschall (1871-1956) was covered with $14.000 \mathrm{~kg}$ of nails (Fig. 2). The Eiserne Hindenburg von Berlin, as the monument came to be known (later "the wooden Titan"), ${ }^{14}$ was removed and put into storage after the war and reportedly largely used as firewood (except for the head which was placed in the Deutsche Luftfahrtsammlung in Berlin in 1938). ${ }^{15}$ The nail men are a typical phenomenon that gained popularity during the First World War. The first Nagelmänner emerged in the spring of 1915; by 1918 hundreds of nail figures had been made, mostly in Germany and Austria Hungary. They represented not only military figures, but also symbols such as coats of arms and iron crosses. ${ }^{16}$ 
Often these resulted from grassroots initiatives by local communities (for instance schools or charity organisations) raising money for war-related aid organisations. The communities participated either directly in the nailing itself, or indirectly by purchasing or supplying iron silver- or gold-plated nails. ${ }^{17}$ The ephemerality of these sculptures is complex. On the one hand, the wooden sculpture is made more durable through the application of nails; on the other hand, the massive application of nails eventually destroyed the wooden structure.

\section{Temporary Memorials in Occupied Belgium}

As the examples above demonstrate, temporary memorials were conceived in a remarkable variety of shapes, materials and sizes. In occupied territories like Belgium, monumental or eye-catching memorials, even when temporary, were largely forbidden. One thus had to resort to inconspicuous improvised shrines or memorials. ${ }^{18}$ We can assume that a lot of ephemeral memorials in this fashion were created in the private or domestic space, to be seen only by the members of a specific family or association: a photograph or postcard on the wall adorned with a candle, a cockade or a flower arrangement... These mostly stayed under the radar. The (censored) press was not likely to report on this phenomenon either, making it even more difficult to grasp. On the (semi)public level, it is noticeable that under the occupation religious celebrations and gatherings often took on patriotic undertones and cemeteries became important loci of remembrance. This was reluctantly tolerated by the occupier. ${ }^{19}$

From early on, local inhabitants, parishes, patriotic associations and occasional groups began to erect improvised funerary steles and temporary monuments in cemeteries. These were likewise covered by the mourners with chrysanthemums and wreaths. A few months after the invasion, for instance, in the cemetery of KesselLo near Louvain a fugitive gravestone-like memorial made from earth, flowers and wood was created to mark the mass grave of the 65 Belgian soldiers ${ }^{20}$ who died in nearby Kessel-Lo(o) in August and September1914'21 (Fig. 3). As of December 1914, the grave was managed by the local veteran society (De Bond van Oud-Soldaten van Blauwput-Kessel-Loo) and it is likely that the memorial was created under their auspices. In 1915, they placed an additional temporary wooden cross on the grave, with the inscription "to the memory of our Belgian heroes who died for their country in Kessel-Loo" (“à la mémoire de nos héros belges tombés pour la patrie à Kessel-Loo"). In mid-1915, the group pleaded for a permanent memorial with the city council, but the latter decided it preferred to wait until the end of the war. ${ }^{22}$ 


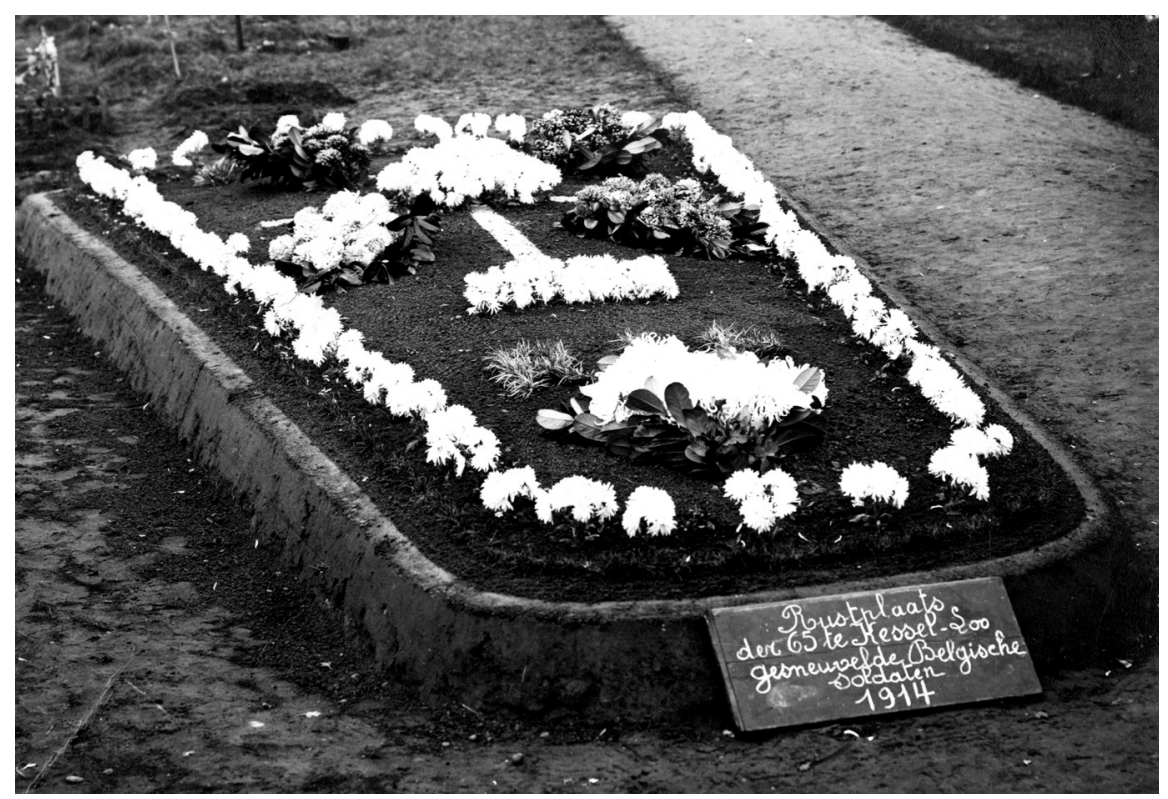

Fig. 3. Temporary memorial at the cemetery of Kessel-Lo (Leuven), 1914. (Leuven City Archive)

The Catholic tradition of laying flowers on the tombs in the local cemetery on All Souls' and All Saints' Day (1-2 November) developed into massive commemorations of the fallen during the war. On those days, monuments related to the allies, such as the French monument for the fallen of 1870 (inaugurated in 1880) and the Wellington Memorial (inaugurated 1890), both at the cemetery of the Brussels commune of Evere, became sites of mourning and patriotic manifestations. In a solemn procession, people walked quietly before the monuments, leaving flowers or lighting candles. At the same cemetery, for All Saints' Day in 1915 a chrysanthemum flower carpet representing the Belgian lion and the initials of the Belgian royals was laid around the graves of the Belgian officers and soldiers who died in Brussels' hospitals following the invasion. At another Brussels cemetery (Saint-Josse-ten-Noode), a temporary monument (probably in plaster) by an unnamed sculptor (the press mentions only that he was a pupil of the famous Thomas Vinçotte (1850-1925)), representing a Belgian lion holding the Belgian flag in its claws mounted on a stone plinth was erected. ${ }^{23} \mathrm{~A}$ year later, in November 1916, a pyramid-shaped wooden memorial was erected at the cemetery of the Brussels district of Ixelles, and a temporary sculptural group embellished the soldiers' cemetery in the nearby municipality of Etterbeek. ${ }^{24}$ Participating in these events was not only a religious token, but also an act of patriotic resistance.

Meanwhile, the occupying regime occasionally celebrated its own heroes with temporary monuments on Belgian soil. In December 1915, a bas-relief of the German 
general Otto von Emmich (1848-1915) - celebrated as responsible for the fall of Liège - was inaugurated in the city's courthouse. It was executed in the traditional Nagelmänner style and came to be called the "Eiserne Emmich". ${ }^{25}$ Von Emmich, who was already gravely ill at the time, died barely a week later. On this occasion, a cast iron bust on a nailed wooden pedestal was erected in Liège as well. ${ }^{26}$ The Belgian exiled press was not impressed by the (particularly German) nail men tradition. A few days before the inauguration of the "Eiserne Emmich", a journalist had commented on the "Eiserne Hindenburg" in terms that can hardly be misunderstood: "this crouched Hindenburg, made out of wood, in which the faithful push nails in iron or gold. A ridiculous spectacle for which the boche illustrated magazines made ample and ludicrous publicity". ${ }^{27}$

What most of these wartime ephemeral sculptures, both in Belgium and abroad, have in common is their co-creation by the local community. While the model of financing public sculptures by subscription was already well-established in the nineteenth century, the tangible and hands-on involvement of the public at large is a feature that came to prominence during the war. The people were involved in both the decision-making process and the actual construction of the memorials and monuments. The nail men - which were literally nailed by the public - are probably the most radical emanation of this trend. But their involvement is also palpable in the snow sculptures, cemetery memorials and street shrines. A second, closely connected feature is their ad hoc nature. These monuments emerge almost unexpectedly and are the result of improvisation. They are built for the most part with non-durable materials that are readily available, such as snow, greenery and derelict wood or metal, and that have been effectively repurposed. As such, they might be considered early examples of "upcycling" and of what design theorists such as Charles Jencks and Nathan Silver, and Joseph Grima call "adhocism" or "adhocracy", which they describe as the art of doing things ad hoc - tackling problems at once, using materials at hand, rather than waiting for the perfect moment or "proper" approach. ${ }^{28}$ Such an ad hoc approach questions authorship, standardisation and bureaucracy; and favours collaboration, sharing and bottom-up initiatives. ${ }^{29}$ This is exactly what also happened in the wartime emanations of ephemeral monuments.

\section{November 1918: An Abrupt Series of Temporary Sculptures in Brussels}

As the Armistice and the end of the war approached, the nature of temporary memorials changed. Design was increasingly prioritised, the prospect of eternalising became more prominent, and official bodies became more and more involved. ${ }^{30}$ The end of the occupation of Belgium in November 1918 was above all a cathartic 
moment. People were finally able to speak out, give in to ecstatic patriotism, and publicly ventilate anti-German sentiments. At the same time, space was created for mourning and commemoration which was no longer limited to the private inner circle or local community. A feeling was shared by many that places of commemoration were important and necessary. Almost instantly, questions arose about whose efforts should first be eternalised in monuments: soldiers, high ranking military, the royals, civilian victims or resisters...? This, of course, brought up the matter of who was to build and finance these memorials, where they should be placed, and what they should look like. It was clear that local or national authorities would play a role in this, but in a state where they were overwhelmed with financial and logistic problems, they initially did not consider monuments a priority and were reluctant to make decisions. As a consequence - and despite the urgency felt by the population the building of official monuments did not start immediately after the Armistice. ${ }^{31}$ At this point, temporary monuments provided an answer. They were less cumbersome to realise and allowed at least temporarily for actual lieux de mémoire to emerge. ${ }^{32}$ Realising that it would take a considerable time to finance and conceive official and expensive permanent monuments, local authorities were interested in involvement in the realisation of these temporary counterparts. These not only offered a possibility quickly to acknowledge military effort and sacrifice but they were also instrumental in the legitimation of the victory of the nation state, and in some cases in consolidating the emerging post-war world order.

In this respect, they were reminiscent of the longstanding tradition of political use of temporary sculpture. Already in the sixteenth century the contribution of artists to patriotic celebrations - such as Joyous Entries or anniversaries of nations and rulers ${ }^{33}$ - through the design of ephemeral sculptures was customary in countries such as Belgium:

In every epoch of our history, Belgian art has largely contributed to rejoicing the fatherland, and the grandest artists have not looked down upon attaching their name to ephemeral creations whose glory helped to perpetuate the memory. ${ }^{34}$

This type of work involved artists from many different trades: architects, stage set designers, decorators, craftsmen, painters, sculptors... In Antwerp, for example, painter Pieter Paul Rubens (1577-1640) created and oversaw the ephemeral decorations for the festive entry of Archduke Ferdinand of Austria in 1634 and turned it into "what was beyond doubt the most splendid of all princely pageants". ${ }^{35}$ Temporary sculptures and architectural contributions remained part of the pomp and circumstance of official celebrations over the centuries. ${ }^{36}$ The close involvement of artists in patriotic celebrations further intensified with the foundation of the nation state 
in 1830. Every year on this national holiday the streets of Brussels underwent a true metamorphosis. The capital was reshaped into a grand open-air fair with flags and pennants, large flower arrangements, paintings and temporary sculptures and architectural structures. These ephemeral artworks had a legitimising, educational and commemorative function: they represented the grandeur and the history of the nation while at the same time contributing to it. The mostly short-lived constructions and adjoining sculptures depicted the glorious past and future of the country and focussed on the monarchy and the constitution to legitimate the nation state. ${ }^{37}$

The use of ephemeral sculptures was also customary in traditional religious, folkloric and historical pageants (which had been common since the late Middle Ages), ${ }^{38}$ and in International and World Exhibitions which Belgium enthusiastically organised in the late nineteenth and early twentieth centuries (Antwerp 1894, Brussels 1897, Liège 1905, Brussels 1910, Ghent 1913). ${ }^{39}$ Joyous Entries, patriotic celebrations, historic and religious pageants and International Expositions were all temporary spectacles, built to be wondered at and then dismantled. To a greater or lesser extent, official bodies were involved in their creation as commissioners and financiers. Through their spectacular qualities, artistic merit and the use of well-known iconographies they consolidated political ideologies.

The first temporary memorials which were erected in Belgium after the war were direct exponents of these traditions. On the occasion of the festive re-entry of the Royal Family into the Belgian capital on 22 November 1918 an exceptional series of ten temporary monuments was made. ${ }^{40}$ Although this event took place 11 days after the actual signing of the armistice (on 11 November 1918), this day was considered the real end of the occupation and marked the beginning of the postwar era in Belgium. ${ }^{41}$ The monuments were commissioned by the city of Brussels and placed in the historic centre as part of the festal decorations. Compared to most wartime temporary memorials, their emergence was obviously less spontaneous and less bottom-up. The enterprise was supervised by city architect François Malfait (1872-1955), assisted by peintres décorateurs Jean Delescluze (1871-1947) and Albert Dubosq (1864-1940). ${ }^{42}$ Next to these lavish decorations, the military parade and the festive atmosphere, the public monuments were an important attraction - they were also photographed and as such disseminated via postcards. The monuments were made in plaster, following the traditional "staff" technique that was also used for the temporary buildings and monuments for the Belgian International Exhibitions and World Fairs. As the project was conceived in the short transitional period between the armistice and the Royal Entry, the usual commissioning procedures for public monuments were not followed, which resulted in fewer restrictions than usual and more freedom for the participating artists. 
As late as mid-November 1918, local newspapers reported that the city council had voted a budget of 500,000 francs for the city's decoration on the occasion of the Royal Entry, including the monuments. ${ }^{43}$ According to the newspaper Le Soir, the sculptors completed their plaster projects in only a fortnight - an almost impossible exploit, as just the casting in plaster of such large models takes a considerable time. ${ }^{44}$ Le Soir spoke of "improvised" monuments, ${ }^{45}$ but it seems - and this is only logical - that most artists involved creatively reused or adapted existing models or designs from their studios. Art critic Sander Pierron (1872-1945) formulated it as such: "[a] not so quite spontaneous flowering, for if some of these works were realised as quickly as the victory of our armies asserted, others had been long conceived and executed in the silence of the workshops" ${ }^{36}$ For instance, Charles Samuel (1862-1938) corresponded already in 1916 with the Brussels' Compagnie des Bronzes concerning his statuette La Brabançonne, which he reworked into a larger, more detailed statue in $1918^{47}$ (Fig. 4). Pierron spoke of "sketches" that would have to be reworked or fine-tuned when later realised in marble or bronze.

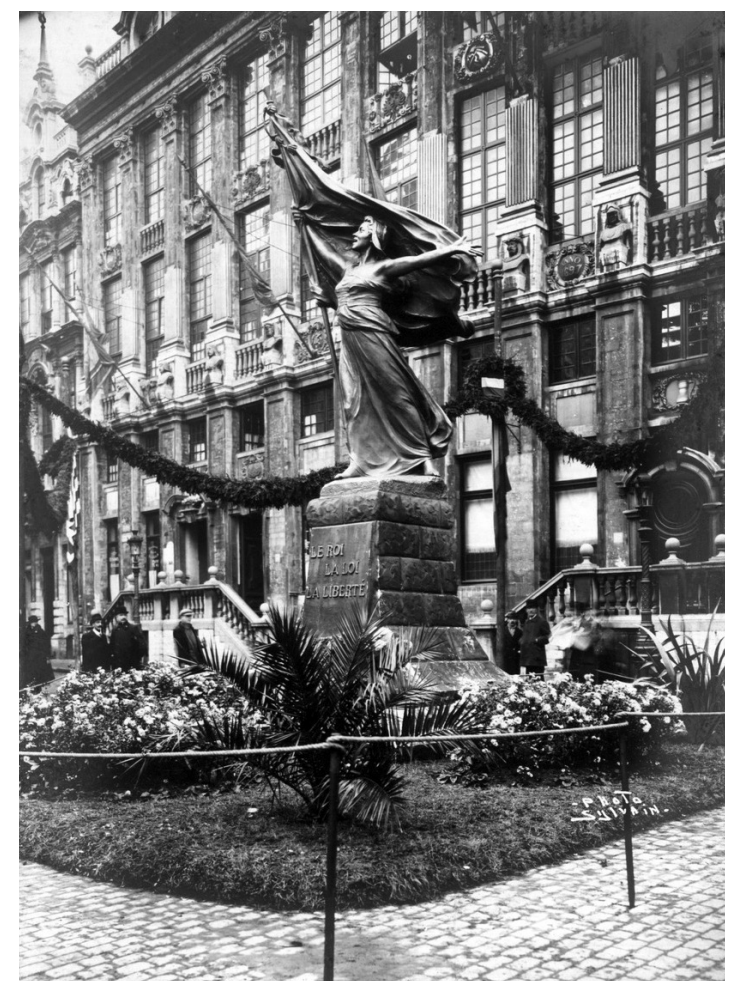

Fig. 4. Charles Samuel, La Brabançonne, plaster and wood, November 1918, Brussels, Grand-Place, photograph Sylvain. (Ghent University Library) 
Apparently, no clear programme, formal guidelines or templates were provided, which left room for improvisation in the design and iconography on the part of the sculptors. As a consequence the monuments varied remarkably in style, genre, height and format, and featured reliefs and busts as well as full-length statues. The allfigurative statues represented personalities as well as small realist groups (the troops, the wounded or grieving women) and semi-nude historical and abstract allegories (e.g. Lady Belgium - sometimes called La Brabançonne - with different qualities, triumphant, fierce or grieving). Moreover, the statues were adorned with patriotic attributes such as flags, lions, Adrian helmets and laurel wreaths in various combinations. The monuments paid homage to a variety of causes in the military sphere: to the heroism and sacrifice of the Belgian soldiers, the wounded soldiers, the British nurse Edith Cavell executed in Brussels ${ }^{48}$ (Fig. 5), King Albert I, the Allies (monuments dedicated to France, Italy, England and the United States) and more abstract subjects such as "liberty", "law" and "peace". By honouring the Allies, international diplomatic concerns were covered. This was much less the case for internal sensibilities regarding the suffering of different groups in the civilian population, who had lived different war experiences (at the front, as resisters in occupied Belgium, in German labour camps, as refugees abroad...). After the war tensions rose between them as to who had suffered most and which experiences should be commemorated (first), influencing post-war decisions about monuments. ${ }^{49}$ Thus, the only semi-improvised nature of the monuments as well as the fact that they were official commissions makes them very much an "in between" series, bridging the transition from war to peace, from ad hoc remembrance to orchestrated commemoration.

Compared to the international avant-garde en vogue at the time, most of the temporary monuments described above were designed in a fairly academic or realist-allegorical style indebted to the nineteenth-century sculptural tradition. After all, these were artworks aimed to appeal to the public at large, to local communities, with particular demands concerning form and content and with a specific function. This led to straightforward, uplifting and recognisable figurative designs. Moreover, several of the authors of the 1918 monuments belonged to the "older" generation (born in the 1850s and 1860s) and had well-established careers. Many were trainees from the Brussels Academy (most of them being pupils of Charles Van der Stappen (1843-1910)) and stemmed from higher social classes. The 1918 project provided them with not only an opportunity to show generosity and patriotism, but also the chance to obtain visibility and remuneration after a grim financial period. The Fédération Professionnelle des Beaux-Arts, set up in September 1914, provided sculptors in occupied Brussels with plaster and a monthly sum in order to help them survive, but they could hardly work and sell during the war. Marble was scarce, and bronze was requisitioned by the occupier from late $1915 .{ }^{50}$ Whereas exhibitions and salons were still organised during wartime in some Brussels museums and galleries, for the 
benefit of the artists in need, they mainly exhibited portraits and salonfähige, charming paintings. Sculptures - even in plaster or terracotta - were largely absent, as were avant-garde works that were considered too much of a risk and thus less attractive for buyers and collectors of art seeking secure investments in times of devaluation. ${ }^{51}$

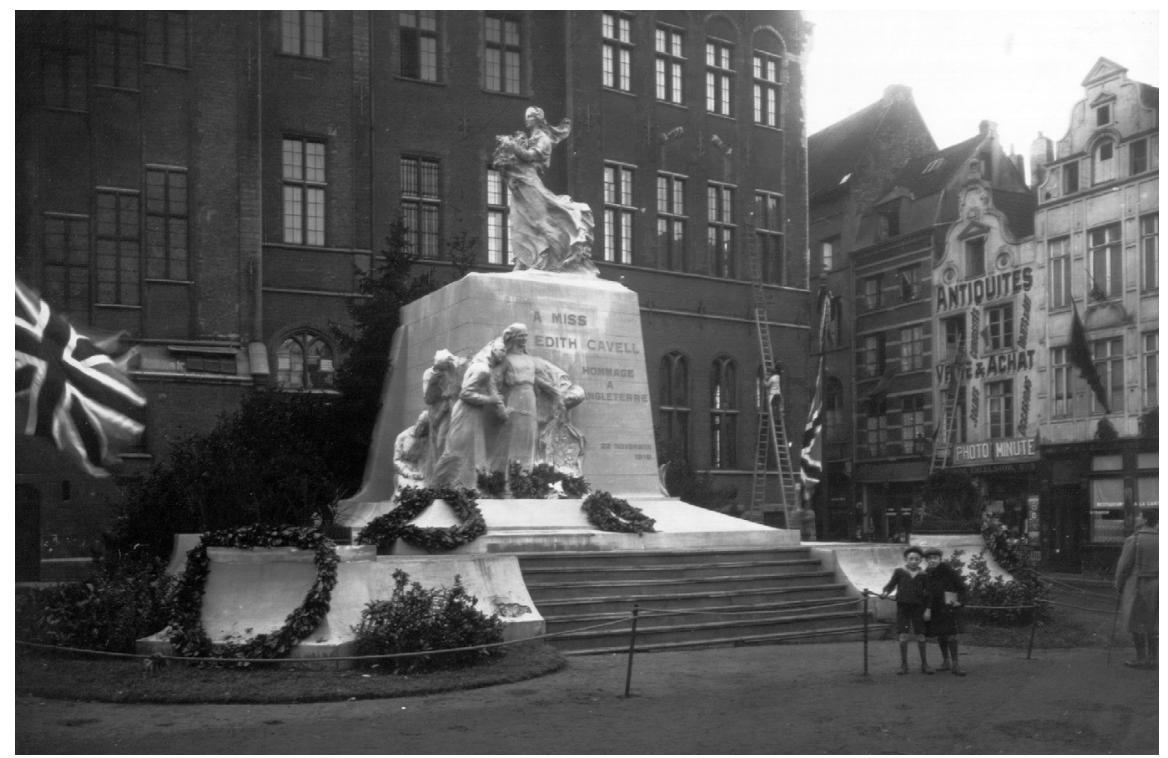

Fig. 5. Jacques Marin, Monument to Edith Cavell, plaster and wood, November 1918, Brussels, GrandPlace, picture postcard. (Brussels City Archive, Guerre 1914-1918 [Monuments provisoires érigés dans la Ville de Bruxelles (en 1918 ou 1919) en reconnaissance aux soldats et victimes de la guerre], C-1879)

\section{Progressing Towards Permanent Memorials... But Not Just Yet}

The statues erected in Brussels in 1918 were made without any immediate prospect of making them permanent, even if Le Belge Indépendant called them "plaster models of future commemorative monuments". ${ }^{52}$ According to the same newspaper, the statues were intended to remain in place until Christmas. Some stayed a few weeks longer, but by February 1919 all sculptures were removed from the public space and most likely returned to their authors or demolished. ${ }^{53}$ However, the monuments had struck a chord, and several plans to perpetuate them were initiated. ${ }^{54}$ Three out of the ten temporary monuments would ultimately be given a permanent character, albeit only after a considerable time and with some minor changes. Not surprisingly, only "unproblematic" monuments representing Belgium in the most general sense were 
retained: Jules Lagae's (1862-1931) monument to King Albert, Guillaume Charlier's (1854-1925) La Belgique reconquise, and Charles Samuel's La Brabançonne (the latter two represent Lady Belgium holding the national flag). Monuments referring to specific groups (À nos blessés by Jos Van Hamme, or À nos soldats morts pour la patrie by Jules Mascré) or to the allies, and monuments airing anti-German sentiments (La Belgique repoussant l'invasion des barbares by the French-born Marquis Jean de Pouilly) disappeared after the festivities.

Samuel's La Brabançonne seems to have been the most popular of the series. It was the last stucco monument to be removed and already before that a possible permanent location was discussed by the Brussels city council. In January 1919, François Malfait suggested the Place de la Chapelle in the popular Marolles neighbourhood, but this idea did not materialise..$^{55}$ In April 1920, on the occasion of the first post-war Brussels Commercial Fair, the plaster monument reappeared briefly in the Royal Park, only to be quickly removed afterwards ${ }^{56}$ Finally in 1930, Samuel's Brabançonne model was cast in bronze to mark the Belgian centenary. Prior to the festivities, money had been raised by public subscription. It was then relocated to the slightly peripheral Surlet De Chokier Square where it still stands today. ${ }^{57}$ The statue was put on a new pedestal and reframed by a new inscription: the first couplet of the national anthem, La Brabançonne. ${ }^{58}$

That only a few of the November 1918 temporary monuments were re-used later is remarkable. Nevertheless, several of the sculptors, most notably Georges Vandevoorde (1878-1964), Léandre Grandmoulin (1873-1957) and Jacques Marin (1877-1950), as well as architect François Malfait, moved on to make war memorials in Brussels and elsewhere in the 1920s and 1930s. Commonplace dedications like "à nos soldats morts pour la patrie" or "à nos héros", which were featured on the early temporary monuments, as well as representations of King Albert, personifications of the Belgian poilu or La Brabançonne, allegories such as the Belgian lion devouring the German eagle, as well as symbols such as the Belgian flag or laurel wreaths were commonly reused in the permanent war memorials. Yet, most of these elements can hardly be considered original. They had been common throughout the war and stemmed from laic iconographical imagery predating the First World War. In that respect, the impact of the 1918 temporary monuments on post-war sculpture was limited.

The temporary monuments erected in Brussels in November 1918 were the first, but certainly not the last, post-war emanation of the urge to commemorate. They were quickly followed by other initiatives, material as well as immaterial. Several patriotic associations established after the war, such as the Ligue des patriotes (Patriotic League) and the Ligue du Souvenir (Remembrance League), aimed for the commemoration of war heroes through immaterial commemorations such as public funerals and remembrance ceremonies. Some associations, such as the Bond der Politieke Gevangenen van den Oorlog (League of Political Prisoners of War), specifically focussed 
on the commemoration of civilian heroes. The latter also became the focal point of remembrance in towns that had suffered exceptionally during the war, such as the villes martyres. In the Walloon village of Tamines for instance, which lost over 380 inhabitants overnight in August 1914, a large wooden cross with a commemorative plaque was erected on the Place Saint Martin immediately after the armistice ${ }^{59}$ (Fig. 6). Although discussions about a permanent official monument of a more suitable design to remember the civilian victims had been ongoing since January 1919, the deteriorating wooden cross was replaced with an almost identical concrete one in 1923. It took another three years, until August 1926, before an official monument in honour of the civilian victims was inaugurated: a sculptural group by Louis Mascré (1871-1927) (also one of the sculptors involved in the 1918 Brussels temporary monuments). In Louvain (Leuven), another ville martyre, a wooden column was erected in the municipal cemetery on 12 January 1919 on the occasion of a patriotic manifestation in honour of the city's civilian martyrs. ${ }^{60}$ Already in December 1915, the city had been planning a permanent memorial for its civilian victims after the war. What followed was a ten-year agony. Finally, the permanent and large-scale "monument to the martyrs" was inaugurated in April 1925. ${ }^{61}$

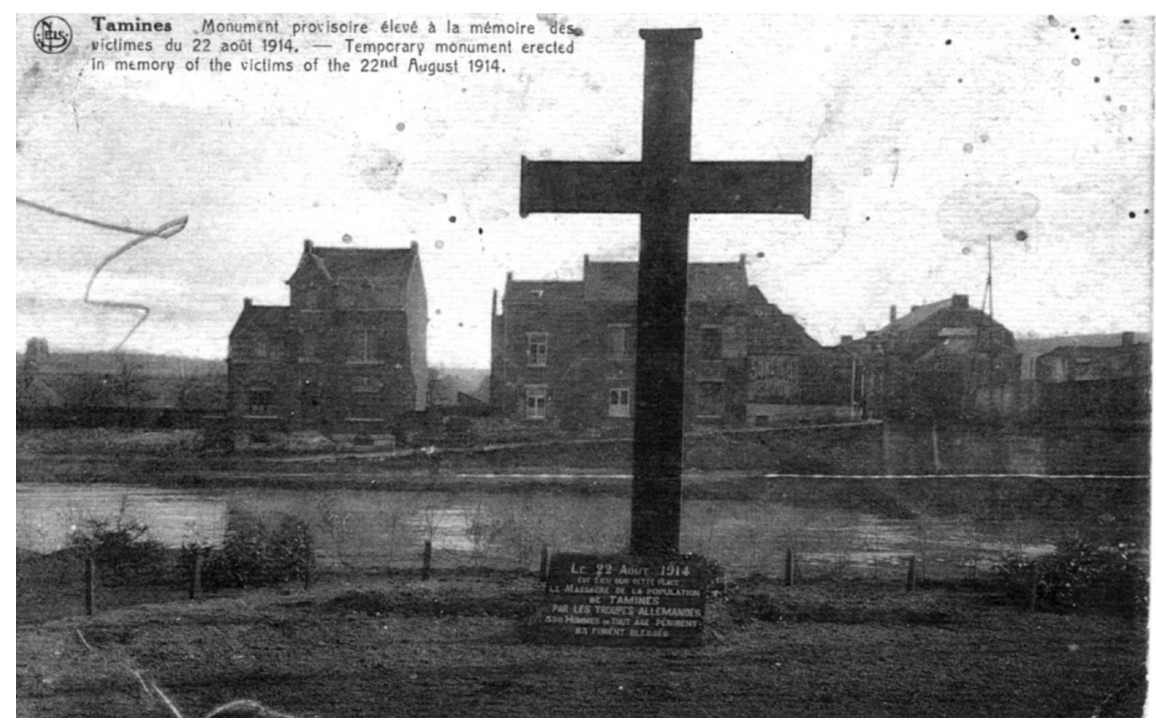

Fig. 6. Temporary monument (cross) erected in memory of the victims of the $22^{\text {nd }}$ August 1914, wood, 1918, Tamines. Picture postcard, Nels, Brussels. (private collection)

On a different scale, a robust temporary cenotaph (an empty tomb) was placed in the park in front of the Royal Palace in Brussels on the occasion of the national jubilee and the subsequent Marche de la Victoire (21 and 22 July) in 1919. The cenotaph 
gave death a literally massive presence amid the victory celebrations. This temporary structure was erected in anticipation of a great national war memorial to be built in Brussels later on - a project that would be abandoned altogether in $1924 .{ }^{62}$ The Brussels cenotaph was designed by city architect François Malfait, and put on the same spot where in November 1918 one of the temporary monuments had stood: Philippe Wolfers's (1858-1929) group of two female nudes, $\grave{A}$ nos héros. ${ }^{63}$ Some ceremonies took place at the cenotaph and it was removed immediately thereafter. Following the capital's example, in 1919 and 1920 provisional cenotaphs appeared in numerous Belgian cities, such as Arlon, Bouillon, Engin, Halen, Halle, Koekelberg, Marcinelle and Mechelen. ${ }^{64}$

As a common typology for a funerary monument, the laic and solemn design of the cenotaph had wide international appeal. In the summer of 1919 temporary cenotaphs were erected in many different countries on the occasion of memorial festivities. For the French national holiday, on 14 July, cenotaphs were raised in several French cities, such as Nancy, Lisieux and Paris, where a short-lived cenotaph was placed under the Arc de Triomphe. ${ }^{65}$ In London, the Peace Parade on 19 July, celebrating the Versailles Peace Treaty, was the occasion for placing a cenotaph by architect Sir Edwin Lutyens in the middle of Whitehall. It remained in situ until it was replaced with a permanent stone cenotaph of roughly the same design in $1920 .{ }^{66}$

\section{Conclusion: Temporary, Untimely and yet Timeless}

This essay has explored the phenomenon of temporary memorials erected during and immediately after the Great War in Belgium. These temporary memorials initiated a trajectory of material commemoration of the Great War that strongly marked the 1920s and 1930s and is still ongoing today. They were conceived to share grief and structure collective commemorations at an "untimely time". During and immediately after the war the grief was overwhelming, and the need for these memorials was deeply felt by the people. At the same time official bodies were paralysed by not only occupation, cumbersome procedures and the lack of financial means and debate, but also a lack of consensus as to who or what was to be commemorated and in what way. Temporary monuments immediately provided for people's commemorative needs and intentions with a locus - a place to grieve and gather. As such, they had a lot in common with their permanent counterparts, from which they differed mostly in terms of their immediacy and their often bottom-up genesis.

Despite their variety, the temporary memorials discussed here shared some important characteristics. First, their creation interactively involved three different actors: the people (usually united in informal or ad hoc groups), (commissioning) 
local authorities or official committees, and the artists and artisans involved in their conception and design. The degree to which each actor was involved depended on both the place and the time the monument was conceived and created. Small and simple memorials emerging during the war - such as street shrines or graves decorated with flowers - were much more bottom-up and the result of ad hoc co-creation by local inhabitants than larger more official memorials such as the November 1918 series of temporary monuments in Brussels and the post-war temporary cenotaphs, created by professional sculptors and architects. The momentum they created allowed for a creative investment of the people and the artists in public space that was hitherto seldom seen.

Yet - and this is a second feature - despite their spontaneous and temporary nature, these temporary memorials were generally not original: their concepts and designs were mostly traditional and timeless. Abstract shapes such as steles, crosses or cenotaphs that could appeal to all were open to a variety of commemorative needs and interpretations and therefore did not require - or instigate - extensive debate. Nor did these designs require the input of the most skilled, famous artists, who were not always readily available. This might also explain why the fleeting character of the temporary memorials did not inspire more daring experiments. Only the larger and more official, top-down initiatives - such as the November 1918 series of temporary monuments in Brussels - displayed considerable artistic and political ambition and as such echoed a long tradition of the use of temporary sculptures and architectural structures in patriotic festivities.

A third shared characteristic of the temporary monuments is their ad hoc character and improvised nature. They went against the grain of bureaucratic procedures and long consensus-oriented debates and were characterised by quick decision-making processes, creative workarounds and the use of readily available materials. Even if their design was traditional, their execution (process) could still be original. This makes the November 1918 series in Brussels all the more exceptional. Thanks to the short time-span and lack of a clear programme, there was room for improvisation and recuperation on the artists' part. No fewer than ten figurative plaster monuments were quickly made, some hastily created from scratch, others based on existing elements or fragments that were recuperated, adapted or reoriented for this purpose. Each monument was dedicated to a specific cause. The series and its "pop-up" wartime precedents preceded or avoided debates about worthy causes, finances and aesthetics that would erupt in full force barely a few months later. They were improvised ad hoc solutions for an "untimely time". 


\section{Notes}

1 "[...] et puis il y aura, il y aurait, si on ne prenait garde quelque chose d'atroce : les monuments commémoratifs !... Dénonçons ce péril. Certes, inscrivons dans le bronze et le marbre, au seuil des maisons communes, les noms des martyrs; plantons des arbres $d u$ Souvenir [...] ; édifions dans quelques grandes villes la colonne ou le temple qui perdurera l'image véhémente et douloureuse de cette époque grandiose. Mais, méfions-nous du monument commémoratif, de prix et de talents réduits, dont nous sommes menacés de tous les coins de l'horizon. [...] Voyez-vous ça? [...] sur toutes les places, une Belgique en bronze, due à l'enfant du pays, [...] N'en doutez pas, d'ailleurs, que chaque Belgique serait aggravée par un lion, le redoutable lion Belgique." (B. L. Souguenet, "En attendant...", Pourquoi Pas?, 12 December 1918.) According to the introduction to the article, the piece was first published by the Parisian weekly La Chronique a few weeks earlier.

See for example: David G. Troyansky, "Monumental Politics: National History and Local Memory in French 'Monuments aux Morts' in the Department of the Aisne since 1870," French Historical Studies 15, no. 1 (1987); Annette Becker, "Monuments aux morts après la Guerre de Sécession et la Guerre de 1870-1871: Un legs de la guerre nationale?", Guerres mondiales et conflits contemporains, no. 167 (1992), https://doi. org/10.2307/25730854; James E. Young, "Écrire le monument: site, mémoire, critique," Annales: Économies, Sociétés, Civilisations 48, no. 3 (1993); Alan Borg, War Memorials from Antiquity to the Present (London, 1991). For an overview of war memorials in the North of France and Belgium see the online database constructed by a research team of the Université de Lille 3: http://monumentsmorts.univ-lille3.fr/. The database is work in progress but aims to be exhaustive by the end of the project.

Stéphanie Claisse, "Pouvoir(s) et mémoire(s). L'État belge et les monuments aux morts de la Grande Guerre," in Une guerre totale? La Belgique dans la Première Guerre Mondiale. Nouvelles tendances de la recherche historique, ed. Serge Jaumain et al., Études sur la Première Guerre Mondiale (Brussels: Algemeen Rijksarchief, 2005); Antoine Prost, "Les monuments aux morts: Culte républicain? Culte civique? Culte patriotique?" in Les lieux de mémoire, ed. Pierre Nora (Paris: Gallimard, 1984).

John Horne, "The Living," in The Cambridge History of the First World War, ed. Jay Winter (Cambridge: Cambridge University Press, 2014), 594. Jay Winter, Sites of Memory, Sites of Mourning. The Great War in European Cultural History (Cambridge: Cambridge University Press, 2003), 80; Mark Connelly, The Great War, Memory and Ritual: Commemoration in the City and East London, 1916-1939 (London: Boydell \& Brewer Ltd, 2015), 25-35. East London Observer, 4 November 1916, 4; 23 December 1916, 5; 10 March 1917, 5.

Connelly, The Great War, Memory and Ritual, 25.

$8 \quad$ "Memorial Cross," Dorking and Leatherhead Advertiser, 12 August 1916, 5.

9 Connelly, The Great War, Memory and Ritual, 35.

10 A photograph of the inauguration is in the Daily Mirror, 5 August 1918.

11 Jeroen Geurst, Cemeteries of the Great War by Sir Edwin Lutyens (Rotterdam: 010 Publishers, 2010), 51-53; Alex King, Memorials of the Great War in Britain: The Symbolism and Politics of Remembrance (London: Berg Publishers, 1998), 55-56. In the extremely harsh winters of, among others, 1660, 1671 and 1672, artists and students from the Antwerp Academy organised an open-air snow sculpture exhibition in the city of Antwerp. The winters of 1511, 1892 and 1901 saw the emergence of the 
snow sculpture exhibitions in Brussels. On this phenomenon, see: Frits Scholten, "Malleable Marble: The Antwerp Snow Sculptures of 1772," Netherlands Yearbook for History of Art / Nederlands Kunsthistorisch Jaarboek Online 62, no. 1 (2012), https:// doi.org/10.1163/22145966-06201011; “Les hivers rigoureux," L'Événement Illustré, 3 February 1917; Herman Pleij, De sneeuwpoppen van 1511. Literatuur en stadscultuur tussen middeleeuwen en moderne tijd (Amsterdam: Meulenhoff, 1988); Martin Warnke, "Schneedenkmäler," in $\mathrm{Mo}(\mathrm{nu})$ mente. Formen und Funktionen ephemerer Denkmäler, ed. Michael Diers (Berlin: Akademie Verlag, 1993).

The Messter Woche 1915, no. 8 is part of the film collection of the Österreichisches Filmmuseum. It can be consulted online through the European Film Gateway (https:// www.europeanfilmgateway.eu.

John W. Wheeler-Bennett, Wooden Titan. Hindenburg in Twenty Years of German History (1914-1934) (New York: William Morrow \& Co., 1936). Karl-Robert Schütze, Der eiserne Hindenburg. Bildergeschichte in Postkarten. Chronologie der Ereignisse und Berichte (Berlin: Schütze, 2007); Hugo Ball, "Der benagelte Hindenburg", Freie Zeitung, 4 May 1918.

For a list of Nagelmänner (by Dietlinde Munzel-Everling), see: http://www.munzel-everling.de/pr_nag.htm (last consulted on 7 July 2020); Dietlinde Munzel-Everling, Kriegsnagelungen, Wehrmann in Eisen, Nagel-Roland, Eisernes Kreuz (Wiesbaden: Munzel-Everling, 2008), 12-34; Gerhard Schneider, In eiserner Zeit. Kriegswahrzeichen im Ersten Weltkrieg (Schwabach am Taunus: BD Edition, 2013). Michael Diers, "Nagelmänner. Propaganda mit ephemeren Denkmälern im Ersten Weltkrieg," in Mon(u)mente. Formen und Funktionen ephemerer Denkmäler, ed. Diers Michael (Berlin: Akademie Verlag, 1993); Munzel-Everling, Kriegsnagelungen. Stéphanie Claisse, Du soldat inconnu aux monuments commémoratifs belges de la guerre 14-18 (Brussels: Académie Royale de Belgique, 2013), 31. Louis Gille, Alphonse Ooms, and Paul Delandsheere, Cinquante mois d'occupation allemande (Brussels: Librairie Albert Dewit, 1919), Tôme 1, 128-129. Later on, this number would be adjusted to 71 . Leuven City Archive, Modern Archive, Coll. Uytterhoeven. The authors wish to thank Liesbeth Coimans for locating the memorial and providing valuable information. A permanent stone memorial was finally erected on the same spot in May 1922. Marc Veldeman, "Voorbijganger gedenk... Monumenten en gedenkstenen rond de Eerste Wereldoorlog te Leuven," in Aan onze helden en martelaren... Beelden van de brand van Leuven (augustus 1914), eds. Marika Ceunen and Marc Veldeman (Leuven: Peeters Publishing, 2004), 267. "À Bruxelles," L'ami de l’ordre, 20 October 1915; "À Bruxelles. Le jour des morts," Le XXe siècle: journal d'union et d'action catholique, 11 November 1915. "Le jour des morts à Bruxelles," Le XXe Siècle: journal d'union et d'action catholique, 14 November 1916. à Londres (London), 15 December 1915.

"À Liège. Le service funèbre de von Emmich," La Belgique nouvelle: journal quotidien indépendant (London), 3 January 1916.

"Ainsi cet Hindenburg accroupi, en bois, où des fidèles enfoncent des clous de fer ou d'or. Spectacle risible auquel les illustrés boches ont fait la plus large et plus sotte publicité". Charles Bernard, "L'idole," Lécho belge: journal quotidien du matin paraissant à Amsterdam, 11 December 1915. 
Charles Jencks and Nathan Silver, Adhocism: The Case for Improvisation (New York: Doubleday/Anchor Books, 1973).

Joseph Grima, "Adhocracy," M+ Matters 1, no. 1 (2012), https://www.mplusmatters. hk/ (last accessed 7 July 2020).

30 In October 1918 a plaster model of François Sicard's (1862-1934) Au poilu was erected on the Champs Élysées in Paris. The model was put in this central place to attract funding. A sign reading "subscribe to the loan" was mounted on its pedestal. The monument was however never realised. In the 1920s Sicard did design several different memorials in France (in Saint-Symphorien, Fécamp and Blois). For pictures of the temporary model on the Champs Élyseés, see the cover of L'Illustration, 26 October 1918. For an eye-witness account, see: H. Pearl Adam, Paris Sees it Through. A Diary, 1914-1919 (London: Hodder and Stoughton 1919), 251.

31 The quarrels about the monuments between the authorities on different levels are discussed in detail in Claisse, Du soldat inconnu, 133-175.

For a discussion on how (temporary) monuments created lieux de mémoire, see: Leen Engelen and Marjan Sterckx, "Herinneringen in steen en op papier. Monumenten en prentbriefkaarten voor twee heldinnen van de Eerste Wereldoorlog: Gabrielle Petit en Edith Cavell," Volkskunde 111, no. 4 (2010): 379-403.

John Rupert Martin, The Decorations for the Pompa Introitus Ferdinandi, vol. XVI, Corpus Rubenianum Ludwig Burchard (London: Phaidon, 1972), 27.

Louis Hymans, XXVe anniversaire de l'inauguration du roi. Les fêtes de juillet, compte rendu des solennités et cérémonies publiques célébrées à Bruxelles les 21, 22 et 23 juillet (Brussels: Alexandre Jamar, 1856), cited in Jeroen Janssens, De Belgische natie viert: de Belgische nationale feesten, 1830-1914 (Leuven: Leuven University Press, 2001), 23. Martin, The Decorations for the Pompa Introitus Ferdinandi, XVI, 17, 178-186. On the occasion of the entry of Charles-Alexandre de Lorraine into Brussels in 1749, for example, several triumphal arches with tableaux representing the prince were erected in Brussels. Christel Stalpaert, "The Entry of Charles-Alexandre de Lorraine into Brussels: Monarchical Discourse in Public Ceremonies and Theatrical Performances," Eighteenth-Century Life 26, no. 2 (2002): 75-76. This article focusses on the role of theatre and ballet during the entry of the prince, highlighting the wide variety of artistic disciplines involved in these ceremonies.

Stefan Huygebaert, "The Quest for the Decisive Constitutional Moment (DCM)," in Sensing the Nation's Law. Historical Inquiries into the Aesthetics of Democratic Legitim$a c y$, eds. Stefan Huygebaert, Angela Condello, and Sarah Marusek (Cham: Springer, 2018); Janssens, De Belgische natie viert 23-39.

Parades such as the Holy Blood Procession in Bruges, the Ommegang in Brussels, the Virga Jesse Parade in Hasselt and the Cortège historique des comtes de Flandre in Ghent featured pageant wagons adorned with monumental decorations and sculptures in stucco in between which figurants in historical costume performed historic or religious scenes. Mario Damen, "The Town, the Duke, his Courtiers and their Tournament: A Spectacle in Brussels, 4-7 May 1439," Studies in Medieval and Early Renaissance art history 69 (2013); Gerard Verbeek, Virga Jesse, schat van de Hasselaar (Hasselt: Comité Zevenjaarlijkse Virga-Jessefeesten, 1988); Davy Depelchin, "De ontwerper als redacteur van een nationale geschiedenis. Het concept van de Gentse Cortège historique des Comtes de Flandre (1849)," Tijdschrift voor Interieurgeschiedenis en Design, no. 40 (2018): 47-67; Chrétien Dehaisnes, Fêtes et marches historiques en Belgique et dans le nord de la France (Lille, 1893). 
Jana Wijnsouw and Marjan Sterckx, "Een machtige veropenbaring der jeugdige Gentsche kunst'. Publieke kunst in het kader van de Gentse Wereldtentoonstelling van 1913," Handelingen der Maatschappij voor Geschiedenis en Oudheidkunde te Gent, no. 66 (2012).

For a longer analysis of this case study, see: Leen Engelen and Marjan Sterckx, "An Ephemeral Open-Air Sculpture Museum: Ten Temporary Monuments for the Festive Return of the Belgian Royal Family to Brussels, November 1918," Sculpture Journal 26, no. 3 (2017): 321-348.

Chantal Kesteloot, “Une nouvelle joyeuse entrée dans Bruxelles libérée," in Albert \& Elisabeth. Le film de la vie d'un couple royal, ed. C. Kesteloot (Brussels: Mardaga, 2014), 86-97.

Bruno Forment, "In kleur en op ware grootte. De operadecors van Albert Dubosq," in Opera. Achter de schermen van de emotie, ed. Francis Maes and Piet De Volder (Tielt: Lannoo, 2011), 228-247. Le Matin, 20 November 1918. "Pour le retour de nos souverains. Les décorations de Bruxelles: un demi-million de crédit voté," Le Soir, 18 November 1918. Le Soir, 23 November 1918. Le Peuple, 4 December 1918: "Floraison pas tout à fait spontanée, car si d'aucunes de ces oeuvres furent réalisées aussi rapidement que s'affirma la victoire de nos armées, d'autres avaient été longuement conçues et exécutées dans le silence des ateliers." Cor Engelen and Mieke Marx, Compagnie des Bronzes de Bruxelles. Archief in beeld (Brussels: Algemeen Rijksarchief, 2002), 348. Engelen and Sterckx, "Herinneringen in steen en op papier," 379-403. Claisse, Du soldat inconnu, 54; Laurence Van Ypersele, Emmanuel Debruyne, and Chantal Kesteloot, Brussel. De oorlog herdacht (1914-2014) (Waterloo: Renaissance du Livre, 2014), 94.

"Among the sculptors, there was great commotion after the requisition of bronze materials. I know folks who keep their best pieces under water in the water tank. Others covered their bronzes with plaster to make them look like plaster casts and put them in between the wet clay sketches on the highest shelves in their studios." ("Chez les sculpteurs, il y eu grand branle-bas par suite de la réquisition des bronzes. J'en connais chez qui des pièces admirables sont au fond de l'eau dans la citerne. D'autres ont recouvert des bronzes d'une couche de plâtre les assimilant à des moulages et les ont mêlés à des ébauches en terre glaise sur les plus hautes planches de leurs ateliers"). Gille, Ooms, and Delandsheere, Cinquante mois, Tôme 4, 288.

51 Werner Adriaenssens, "Belgian Art During the First World War: Exhibitions and Salons in Brussels," in 14-18 Rupture or Continuity. Belgian Art Around World War I, ed. Inga Rossi-Schrimpf and Laura Kollwelter (Leuven: Leuven University Press, 2018), 143-159.

Le Belge Indépendant, 13 December 1918. (“des maquettes en plâtre de futurs monuments commémoratifs").

$53 \quad$ Le Belge Indépendant, 1 February 1919.

54 In early December 1918, an enthusiastic reader of Le Soir advocated in a published letter to the editor the casting of the temporary monuments in bronze and financing them by public subscription. As an answer, Le Soir recommended the selection of the most meritorious monument: "but one could select one of the best and erect it by public subscription". "Une suggestion”, Le Soir, 8 December 1918. ("mais on pourrait en distinguer un entre les meilleurs, et lélever par souscription publique"). 
Letter from the city architect of Brussels to an alderman, 8 January 1919, Brussels City Archives, A, D8, nr. 71; as mentioned by Cathérine Leclercq, "Standbeelden en monumenten van Brussel na 1914," in De beelden van Brussel, ed. Patrick Derom and C. Marquenie (Brussels \& Antwerp: Patrick Derom Gallery - Pandora, 2000). As appears from a rare picture postcard of this Fair, the statue was then installed in the Royal Park facing the Royal Palace, almost where Lagae's King Albert memorial was positioned in November 1918. The monument was now placed on a new plinth, with the same inscription but without the explicitly war-related bas-relief decoration. The statue was inaugurated on 16 November 1930. See: Leclercq, "Standbeelden en monumenten," 207-209.

"ô Belgique, ô mère chérie, À toi nos cœurs, à toi nos bras, À toi notre sang, ô Patrie! Nous le jurons tous, tu vivras!". Initially there existed only a French version of the anthem. In 1938 an official Flemish translation was accepted. This text was added to the plinth of La Brabançonne later on.

During the German siege of Tamines on 21-22 August 1914, 383 civilians lost their lives and another 98 were wounded. Tamines was first mentioned as a martyred city in 1915: Marius Vachons, Les villes martyres de France et de Belgique: statistique des villes et villages détruits par les Allemands dans les deux pays (Paris: Payot et Cie 1915), 166-167.

60 Veldeman, "Voorbijganger gedenk," 261.

61 Marika Ceunen, "Wat een monument lijden kan... Oprichting, lotgevallen en restauratie van het oorlogsmonument op het Martelarenplein," in Aan onze helden en martelaren... Beelden van de brand van Leuven (augustus 1914), ed. Marika Ceunen and Marc Veldeman (Leuven: Peeters Publishing, 2004), 305-320.

On 14 July 1919, a resolution was adopted confirming the intention to build a great national war memorial in Brussels. In the following years, several locations and artists were proposed but no consensus was reached. Eventually, the state settled for the burial of an Unknown Soldier in 1922 at the foot of the Congress Column in Brussels. The latter was built in the 1850s to commemorate the founding of Belgium and the Belgian Constitution in 1830. In 1924, this grave was completed with an eternal flame and the project to build a national war memorial was abandoned altogether. Claisse, "Pouvoir(s) et mémoire(s)".

63 Stéphanie Claisse, "Les monuments aux morts," in De la guerre de l’ombre aux ombres de la guerre, eds. Laurence Van Ypersele and Emmanuel Debruyne (Brussels: Éditions Labor, 2004), 65.

64 Cited in Claisse, Du soldat inconnu, 63-64.

65 This location was used for temporary monuments on several occasions. In 1885, for example, a catafalque for Victor Hugo (by Alexandre Falguière and Marguerite Syamour) was erected on the same spot. In July 1919 an additional, peculiar temporary memorial was installed at the roundabout of the Champs Elysées: The Coq Gaulois of 1914 Surveying the Pyramid of German Guns, consisting of a plaster sculpture of the Gallic rooster triumphing over a pile of captured German canons.

66 Jay Winter, Sites of Memory, Sites of Mourning, 102-105; Geurst, Cemeteries of the Great War, 52-55. 

